\title{
Cultural Elements in "Sentono Genthong" Folklore of Pacitan Regency as Literary Learning in Senior High Schools
}

\author{
Rizqi Citania Sari ${ }^{1}$, Suyitno ${ }^{2}$, Nugraheni Eko Wardani ${ }^{3}$ \\ ${ }^{123}$ Postgraduate of Indonesian Language Education, Faculty of Teacher Training and Education, Universitas \\ Sebelas Maret, Indonesia \\ rizqicitaniasari@student.uns.ac.id
}

\begin{abstract}
This aimed to describe the cultural elements in SentonoGenthong folklore in Pacitan Regency as literary learning in senior high schools. This research applied a qualitative method with an ethnographic research approach that emphasizes data on citations to folklore obtained from the results and transcripts of participant interviews and data sources from SentonoGenthong folklore in Pacitan Regency. The data were collected through interviews, observation, documentation, field notes, and transcription. They were then analysed using aspects of description, analysis, and interpretation. This research used triangulation of sources, methods, and theories. This research unravelled the description of the cultural elements in the SentonoGentong folklore in Pacitan Regency, namely (1) language systems, (2) knowledge systems, and (3) religious systems.
\end{abstract}

Keywords : cultural element; folklore; sentonogenthong; literary learning

\section{Introduction}

Good education is education that can prepare students to be able to access their roles in the future. It means that education should be able to equip students with a variety of skills needed in accordance with the circumstances of the era, so that they can run and fulfil their life goals effectively and efficiently. In other words, education is an effort to improve character, mind, and body that is in harmony with nature and society through culture (Wibowo, 2013).

The concept of culture has a very broad meaning, which is the whole mind and the results of human work as a learning process in the activities of life. This is in line with the opinion of (Taylor, 1898) that culture it is also referred to as "civilization" which contains a very complex understanding of a nation including knowledge, beliefs, art, morals, laws, customs, habits and other traits obtained from the community.

According to the opinion of (Kroeber, Kluckhohn, Untereiner, \& Meyer, 1967), culture consists of various behaviours, feelings, and reactions obtained and derived by the symbols that make up its own achievements from groups of humans, including the embodiment of material objects. The core of culture consists of traditions of ideals or understanding, especially its relationship with values. (Ratna, 2011) And (Koentjaraningrat, 2009) said that due to the broadness meaning of culture, it needs to be broken down and analysed into elements of universal culture including (1) language, (2) knowledge systems, (3) social organizations, (4) living equipment systems and technology, (5) livelihood systems, (6) religious systems, and (7) arts.

Indonesia has a diverse local culture with many ethnic groups. The birth of local culture has become a life guide for certain community members because the noble values of culture consist of concepts about everything that is considered important and valuable. One of the local cultures is the SentonoGenthong folklore, precisely located in Krajan Sub-Village, Dadapan Village, Pringkuku District, Pacitan Regency, East Java, Indonesia. SentonoGenthong is a historical site in the form of traces of the ruins of ancient people. Genthong in Javanese means water storage made of clay. It is unique because it contains bones. The bone is believed to have meaningful messages. Rumour has said if a visitor sees upright, long and white bones, it means 
that he/she will live long and be fortunate. Conversely, if someone sees a short and small bone, it will shorten his/her life and he/she will have lack of fortune. According to the folklore, the bone belongs to King Brawijaya $\mathrm{V}$ who intended to sacrifice his hand when approaching moksa (a concept of Hinduism and Buddhism), which means freedom from worldly ties and escape from the circle of life reincarnation.

The existence of SentonoGenthong is associated with stories from Ngerum Kingdom. Once upon a time, King Ngerum was amazed by the beauty of the land of Java that he had never met before. For him, Javanese land was a heavenly land, saving the diversity of plasma mutfah in the grace of Mother Nature. Unfortunately, the land was still empty. No humans had inhabited it. Then, he sent wadyo bolo (troops) to expand the area and make Java as a place to live. However, far beyond expectations, none of the 40,000 wadyo bolos survived. The King received the bad news. Behind its beautiful image, the land of Java has now become a land of wingit (haunted). It turned out that the land of Java was inhabited by spirits who were able to ravage all human life to death. Then, the King ordered the Necromancers of the kingdom (people who could predict a situation by looking at stars) to give sacrifice to the land of Java so that it could be inhabited by humans.

Besides the story of King Ngerum, apparently there was also a story from King Brawijaya V. At that time, Majapahit Kingdom almost collapsed. King Brawijaya V and a court servant (guard) travelled west of Pacitan to perform a meditation (hermitage). Pacitan was chosen probably because there were many caves suitable for meditation. For him, watching the nature of Pacitan is something that is interesting and very decent for future humans. King Ngerum also believed thatPacitan (one of the areas in Java) wasvery mystical. Thus, no human can live there. Therefore, before the King's moksa, he advised the court servants to cut the bones of his right hand (King Brawijaya V's hand), put it into genthong, and put it on the mountaintop of Karang so that the people of Pacitan could safely inhabit.

SentonoGenthong is like a language in a sign system that contains elements of the signified and signifier. In this case, SentonoGenthong is a physical object (signifier) while the messages are the signified. Then, what signifier can be learned from the story of SentonoGenthong? If examined, the two versions of the story of King Ngerum and King Brawijaya V describe the same moral value about sacrifice. The term sacrifice comes from the word victim, which means giving to express worship, loyalty, and so on. While an offering means something that is used to reject (illness and so on), tolakbala (offerings and so on) to get something better. It can be interpreted that the sacrifice in question is the willingness of King Ngerum and King Brawijaya V to mobilize all their abilities for the sake of the lives of many people and the offering referred to is as a tool to sacrifice.

The SentonoGenthong object and everything inherent in it are pieces of life that are ready to be compiled to reach the peak of the full meaning. The term offering can be interpreted as a symbolic function to convey the ancestral heritage (primacy of life) to human civilization from generation to generation. In addition, it is also a tool to make human beings always have a willingness to sacrifice for others. On one hand, the sacrifice placed on the top of Mount Karang is interpreted that the mountaintop is the highest place on earth surface. Therefore, willingness to sacrifice for the common good should be put on the top (above) or beyond the self-interest (personal interest). That way, it will form a human character that is teposliro (tolerant), not greedy and respects each other in living life together.

The myth of SentonoGenthong experiences the novelty of meaning as well as inspiration for the next life even though the meaning is subjective and tends to be multiple interpretations 
back to purityand is autonomous from the object itself. If currently SentonoGenthong is the main destination for tourists, then their hopes of exploring Mount Karang are not only a physical and aesthetic journey. The rest is a journey about climbing the peak meaning beyond the treatise of ancient buildings.

SentonoGenthong is part of the historical folklore that a nation has as a cultural richness. This is as stated by (Dorson, 2016), (Danandjaja, 1991), and (Dundes, 1980) that folklore is part of a literary work that contains culture and growth in each region and becomes a heritage object. If it is revealed in, there are many interesting folklores to be studied for research in various communities or regions because they have various aspects of people's lives adopted from the past.

(Peraturan Pemerintah Republik Indonesia Nomor 57 Tahun 2014, n.d.) concerning Development, Guidance, Protection of Language and Literature, and Enhancing the Function of Indonesian Language Article 24 paragraph 2 states the development of Local Literature is carried out through: (1) literary education; (2) literary training; (3) providing facilities to encourage the development of the literary community; (4) providing facilities for the provision of literary works; and (5) discussing a suitable atmosphere for literature, which can be done in folklore that needs to be protected and preserved from extinction for future generations by allowing Indonesian Language teaching materials in literary learning in senior high schools to be in accordance with core and basic competencies that must be achieved. In addition, it can teach students to always be close to the concrete situations they face daily, which have high relevance for life development skills and become a vehicle to foster and develop students' democracy optimally and help educators grow their students' interests towards literature.

This research aimed to explore the cultural elements contained in SentonoGenthong folklore in Pacitan Regency as a literary learning in senior high schools. The researcher used a holistic approach, so that the analysis used emic data (participant's views) and ethical data (researchers' views) as practical purposes. From several researches that have already been conducted, the research of (Komariah, 2018) discussed Kuningan folklore which is used as an introduction to the assessment of character education and appreciation of literature in junior high schools, (Suwarno, Saddhono, \& Wardani, 2018) discusses history, education, and the character education values in the Naga river folklore. (Youpika \& Zuchdi, 2016).Discusses the folklore of Pasemah Tribe Bengkulu and the character education values contained in it as well as its relevance as literary learning material in elementary schools.(Nugroho, Azwandi, \& Susetyo, 2013) discussed MusiRawas folklore used as the development of teaching materials in elementary schools. (Indriyani, 2015) discusses Banyuwangi South Garut folklore as the media for character education and preservation of local wisdom and discusses the Makyong theatre as material for literary learning in senior high schools.

\section{Research Methods}

This research is qualitative research with ethnographic research approach. According to (Moleong, 2017), qualitative research uses a scientific background to interpret the phenomena that occur and discuss existing methods. Then, (Creswell, 2013) says that ethnographic research discusses social issues from community groups that can support them. The research data were the excerpts of folklore obtained from the participant interview results and transcripts. The data source of this research is SentonoGenthong folklore in Pacitan Regency. 
The data were collected through interview, observation, documentation, field notes, and transcription.

There are three aspects of ethnographic data analysis, namely description, analysis, and interpretation (Creswell, 2013). The three steps were objectively matched to examine the cultural elements in SentonoGenthong folklore in Pacitan Regency. The data description in this research involves the process of arranging, developing, and writing. At the first stage, the researcher arranged objectively the sequence of the story, and then developed it with plots and characters. After that, she wrote the story in accordance with the analysis that contains cultural elements. At the second stage, the researcher analysed the data in the forms of (1) cultural elements of the language system; (2) cultural elements of the knowledge system; and (3) cultural elements of the religious system. They were then grouped through tables systematically. At the third stage, the researcher interpreted the findings of data on cultural elements in folklore to be concluded. This research also used data triangulation, namely (1) source triangulation, (2) method triangulation, and (3) theory triangulation.

\section{Results and Discussion}

The results of this research describe and explain the cultural elements of SentonoGenthong folklore in Pacitan Regency as literary learning in senior high schools, which include: (1) cultural elements of the language system, (2) cultural elements of the knowledge system, (3) cultural elements of the religious system.

\subsection{Cultural Elements of the Language System}

Language is a product of humans as homo languens.Language is a tool or embodiment of culture that humans use to communicate with each other or have relationship. Human language was initially manifested in the form of a sign (code), which was then refined in the form of spoken language, and finally into written language. This is proven in the following data:

\section{"While the Genthong is made of clay and the colour is still new." (page 1)}

From the above excerpt, it can be described and explained that there is a cultural element of the language system because the word Genthong comes from the Javanese language which means water storage.

"The wuwung is made of the fibres of palm or enau tree." (page 2)

From the above excerpt, it can be described and explained that it contains cultural element of the language system because the word wuwung comes from the Javanese language which means roof.

"While people assume that the loss of the balung (bone) is not taken by people." (page 3)

From the above excerpt, it can be described and explained that it contains the cultural element of the language system because the word balung comes from the Javanese language which means bone.

\subsection{Cultural Elements of the Knowledge System}

The knowledge system is a product of humans ashomo sapiens.Knowledge is everything that humans know about objects, their nature, circumstances, and expectations. Knowledge is owned by all ethnic groups in the world. They acquire knowledge through experience, intuition, 
and thinking according to logic or empirical experiments (trial and error).Knowledge can be obtained from one's own thoughts. In addition, there are also other people's thoughts. This is proven in the following data:

"Besides that, according to the caretaker story that the plants around Mount Karang next to SentonoGentong also have the benefit of curing diseases." (page 5)

From the above excerpt, it can be described and explained that there is a cultural element of the knowledge system because it discusses about the environment which has benefits for human life.

"SentonoGentong is a former site of previous people who are considered sacred and miraculous." (page 5)

From the above excerpt, it can be described and explained that it contains the cultural element of the knowledge system because it discusses the trait or behaviour of ancient people.

\subsection{Cultural Elements of the Religious System}

The religious system is a product of humans as homo religious.Humans, who have the intelligence of the mind and feeling, realize that there is the power of the Greatest (supernatural) above theirs that can "black-whiten" their lives. This is proven in the following data:

"Many people who come on pilgrimages come to give shodaqoh." (page 5-6)

From the above excerpt, it can be described and explained that there is a cultural element of the religious system because it deals with public trust.

"So, the native Javanese people are descended from Hindustani people." (page 6)

From the above excerpt, it can be described and explained that it contains the cultural element of the religious system because it discusses the values and views of life because most people in the past were Hindus.

The findings of the researcher revealed that in SentonoGentong folklore in Pacitan Regency as literary learning in senior high schools there are cultural elements, namely the language system, knowledge system, and religious system. These cultural elements are a mirror of the socio-cultural life that develops in the community so that they are able to contribute positively. In this case, it is in line with the research of (Fitriani, 2019) about GunungKelud folklore using mythological analysis and educational values, which were used as teaching materials in junior high schools. This research used Sentono Genthong folklore, which were analysed through cultural elements and used as literary learning in senior high schools.

\section{Conclusion}

This research concludes that SentonoGenthong folklore in Pacitan Regency is one of the folklores of historical heritage sites that are widespread in the community with all its features. Thus, it can be used as a means of literary learning media for senior high schools as well as cultural preservation efforts so as not to be forgotten by young generations. In this folklore, the researcher describes and explains the concepts of cultural elements which include (1) cultural elements of the language system, (2) cultural elements of the knowledge system, and (3) cultural elements of the religious system. The language system includes oral and written language. The knowledge system includes the environment, flora and fauna, space and numbers, the trait and behaviour of fellow humans, and the religious system includes beliefs, values of life, and religious communication. 


\section{Acknowledgements}

Thanks to all those who have helped to take part in the preparation of the article, especially the supervisors and editorial board of the journal. The author hopes that this research can contribute specifically to the education domain of nations and countries throughout the world.

\section{References}

Creswell, J. W. 2013. Qualitative Inquiry and Research Design Choosing among Five Traditions. London: SAGE Publications, Inc.

Danandjaja, J. 1991. Folklor Indonesia: Ilmugosip, dongeng, dan lain-lain (Indonesian Folklore: Science of gossips, fairy tales, and others). Jakarta: PT PustakaUtamaGrafiti.

Dorson, R. M. 2016. Folktales Told Around the World. Chicago and London: The University of Chicago Press.

Dundes, A. 1980.Interpreting Folklore.Bloomingtoon: Indiana University Press.

Fitriani, P. 2019. Analisis Mitologi dan Nilai Pendidikan pada Cerita Rakyat Gunung Kelud serta Relevansinya sebagai Bahan Ajar di SMP (Analysis of Mythology and Educational Values on Mount Kelud Folklore and Its Relevance as Teaching Materials in Middle School), Thesis: Faculty of Teacher Training and Education, Universitas Sebelas Maret Surakarta.

Indriyani, I. (2015). Cerita Rakyat Batuwangi Garut Selatan sebagai Media Pendidikan Karakter dan Pelestarian Kearifan Lokal (Batuwangi Folklore of South Garut as a Character Education Media and Preservation of Local Wisdom). RiksaBahasa: JurnalBahasa, Sastra dan Pembelajarannya, 1(1): 86-92.

Koentjaraningrat. 2009. Pengantar Ilmu Antropologi (Introduction to Anthropology). Jakarta: PT. RinekaCipta.

Komariah, Y. (2018). Pengembangan Bahan Ajar Cerita Rakyat Kuningan Terintegrasi Nilai Karakter dalam Pembelajaran Apresiasi Sastra di SMP (Development of Integrated Kuningan Folklore Teaching Materials with Character Values in Literature Appreciation Learning of Middle School).Dieksis: Jurnal Pendidikan Bahasadan Sastra Indonesia, 5(1): 100 .

Kroeber, A. L., Kluckhohn, C., Untereiner, W., \& Meyer, A. G. 1967.Culture: A Critical Review of Concepts and Definitions. Cambridge: The Museum.

Moleong, L. J. 2017. Metode Penelitian Kualitatif(Edisi Revisi) (Qualitative Research Method (Revised Edition)) Bandung): PT. Remaja Rosdakarya

Nugroho, A., Azwandi, A., \& Susetyo, S. 2013. Pengembangan Bahan Ajar SastraBerbasis Cerita Rakyat MusiRawas Kelas V SD Negeri KaryadadiKabupatenMusiRawas (Development of Literary Teaching Materials Based on MusiRawas Folklore for Class $\mathrm{V}$ at Karyadadi Elementary School in MusiRawas Regency), Thesis: Postgraduate of Universitas Bengkulu.

Government Regulation of the Republic of Indonesia No. 19 of 2014.Development, Guidance, Protection of Language and Literature, and Enhancing the Function of Indonesian Language.

Putri, A. K., Suyitno, \& Rohmadi, M. (2019). The Function of Makyong Teather of "Cerita Putri Ratna" on Literature Learning in Senior High School. Budapest International 
Research and Critics Institute (BIRCI-Journal): Humanities and Social Sciences, 2(2): 165-170.

Ratna, N. K. 2011. Antropologi Sastra: Peranan Unsur-Unsur Kebudayaan dalam Proses Kreatif (Anthropology of Literature: The Role of Cultural Elements in the Creative Process). Yogyakarta: PUSTAKA PELAJAR.

Sarwono, S., Saddhono, K., \&Wardani, N. E. (2018). Sejarah, UnsurKebudayaan, danNilai Pendidikan Karakter dalam Legenda Sungai Naga (History, Elements of Culture, and Values of Character Education in the Legend of the Dragon River). RETORIKA: Jurnal, Bahasa, Sastra, dan Pengajarannya, 11(2): 194-203.

Taylor, E. B. 1989. Anthropology. London: John Murray, Albemarle Street.

Wibowo, A. 2013.Pendidikan Karakter Berbasis Sastra: Internalisasi Nilai-Nilai Karakter Melalui Pengajaran Sastra (Literature-Based Character Education: Internalization of Character Values Through Literary Teaching). Yogyakarta: PUSTAKA PELAJAR.

Youpika, F., \&Zuchdi, D. (2016).Nilai Pendidikan Karakter Cerita Rakyat Suku Pasemah Bengkulu dan Relevansinya sebagai Materi Pembelajaran Sastra (Character Education Values of Pasemah Tribe Folklore in Bengkulu and Its Relevance as Literary Learning Material).Jurnal Pendidikan Karakter, (1): 48-58. 